\title{
Integrated Water Management for Environmental Flows in the Rio Grande
}

\author{
S. Sandoval-Solis, A.M.ASCE${ }^{1}$; and D. C. McKinney, M.ASCE ${ }^{2}$
}

\begin{abstract}
In the Rio Grande transboundary basin, environmental flows have not been considered as an integral part of the water management. This research focuses on the Big Bend, a reach located along the Rio Grande mainstem. Important natural regions of the Chihuahuan Desert are threatened due to the lack of environmental flows. In this paper is estimated the maximum volume of water available for environmental flows without affecting human and international water requirements, and without increasing the flood risk in Presidio-Ojinaga. Environmental flows are proposed based on an analysis of the prior reservoir alteration hydrology of the river. A planning model was built to simulate the water allocation system and evaluate alternative policies. A reservoir reoperation policy for Luis L. Leon reservoir is proposed to supply environmental flows without violating the system constraints. The policy that supplies the maximum water to the environment is two-thirds (66\%) of the prior reservoir alteration conditions; it also improves human water supply, treaty obligations, and decreases flood risk. DOI: 10.1061/(ASCE)WR.1943-5452.0000331. () 2014 American Society of Civil Engineers.
\end{abstract}

Author keywords: Environmental flows; Reservoir reoperation; Integrated water management; Adaptive management; Rio Grande.

\section{Introduction}

Water management that attempts to balance competing uses is a common factor in many modern water resource systems. Sustainable water systems are those designed to meet present and future water demands, while maintaining a range of hydrologic variation necessary to preserve the ecological and environmental integrity of the basin (Loucks 1997). The previous definition contains several uncertainties. What is the current and future water availability? This estimation is undetermined given the alteration of nature by humans, land use change, greenhouse gas emissions, and climate change. What are society's water needs now and in the future? It is challenging to define current water needs and anticipate the values that future generations will impose on water and natural resources. What is the environmental integrity of the basin? It is difficult to determine the future water requirements and land use practices to preserve the environment. This paper presents an integrated water management approach to meet current and future water needs, while rehabilitating some elements of the native ecosystem, considering the historic hydrology of a specific basin-the Rio Grande.

Achieving sustainability in transboundary basins is challenging due to the existence of international agreements. This is the case of the Rio Grande/Bravo Basin (RGB Basin); a transboundary basin shared by the United States and Mexico [Fig. 1(a)]. Environmental flows have not been considered as part of the water management in the RGB Basin. This paper focuses on the Big Bend Reach (BB Reach), a region situated along the Rio Conchos mainstem from Luis L. Leon (LLL) Reservoir to its confluence with the RGB Basin and along the RGB Basin mainstem from the cities

\footnotetext{
${ }^{1}$ Assistant Professor, Dept. of Land, Air and Water Resources, Univ. of California at Davis, Davis, CA 95616. E-mail: samsandoval@ucdavis.edu

${ }^{2}$ Professor, Center for Research in Water Resources, Univ. of Texas at Austin, Austin, TX 78712 (corresponding author). E-mail: daene@ aol.com

Note. This manuscript was submitted on March 1, 2012; approved on November 6, 2012; published online on November 8, 2012. Discussion period open until August 1, 2014; separate discussions must be submitted for individual papers. This paper is part of the Journal of Water Resources Planning and Management, Vol. 140, No. 3, March 1, 2014. (C) ASCE, ISSN 0733-9496/2014/3-355-364/\$25.00.
}

of Presidio-Ojinaga to Amistad Reservoir [Fig. 1(b)]. Important pristine areas such as the Big Bend National Park in the United States; the Maderas del Carmen, Cañon de Santa Elena, and Ocampo Natural Reserve Areas in Mexico are threatened due to the lack of water management for environmental purposes. In 2010, a joint statement by Presidents Barak Obama (U.S.) and Felipe Calderon Hinojosa (Mexico) recognized the fragility and uniqueness of this region; they instructed their staff to initiate a process to recognize and designate Big Bend as a natural area of binational interest (Obama and Calderón 2010).

Since 2008, an independent group of scientists and individuals, from both countries, have explored several strategies to improve the environmental conditions in the BB Reach, including the feasibility of providing environmental flows (e-flows) because of its unique characteristics: (1) there is water flowing in the reach but the flow regime is not optimal for environmental purposes; (2) infrastructure already exists to deliver e-flows from LLL Reservoir on the Rio Conchos in Mexico; and (3) water for e-flows is not a consumptive use (except for the conveyance losses), water releases from LLL Reservoir are captured below BB Reach in Amistad Reservoir. The main problems associated with an environmental policy are: (1) about $80 \%$ of the water in this region comes from Mexico namely the Rio Conchos, equity issues arise because in order to provide environmental benefits to both countries most of the water comes from Mexico; (2) there is a high-flood risk at PresidioOjinaga Valley (P-O Valley), any environmental policy must consider the flood risk in this area; and (3) any e-flows policy must follow the water division between the United States and Mexico stated in the Treaty of 1944 [International Boundary, and Water Commission (IBWC) 1944].

How much water does the environment need? How much water is available for environmental purposes? Where could this water come from? This research proposes a set of e-flows based on a streamflow analysis of the basin. Then, a water management policy is proposed to supply e-flows that consider all the water sources, system constraints, and local and international water allocation rules. The objective of this research is to estimate the maximum volume of water available for e-flows in the BB Reach, the maximum physically feasible solution. These values will be useful 


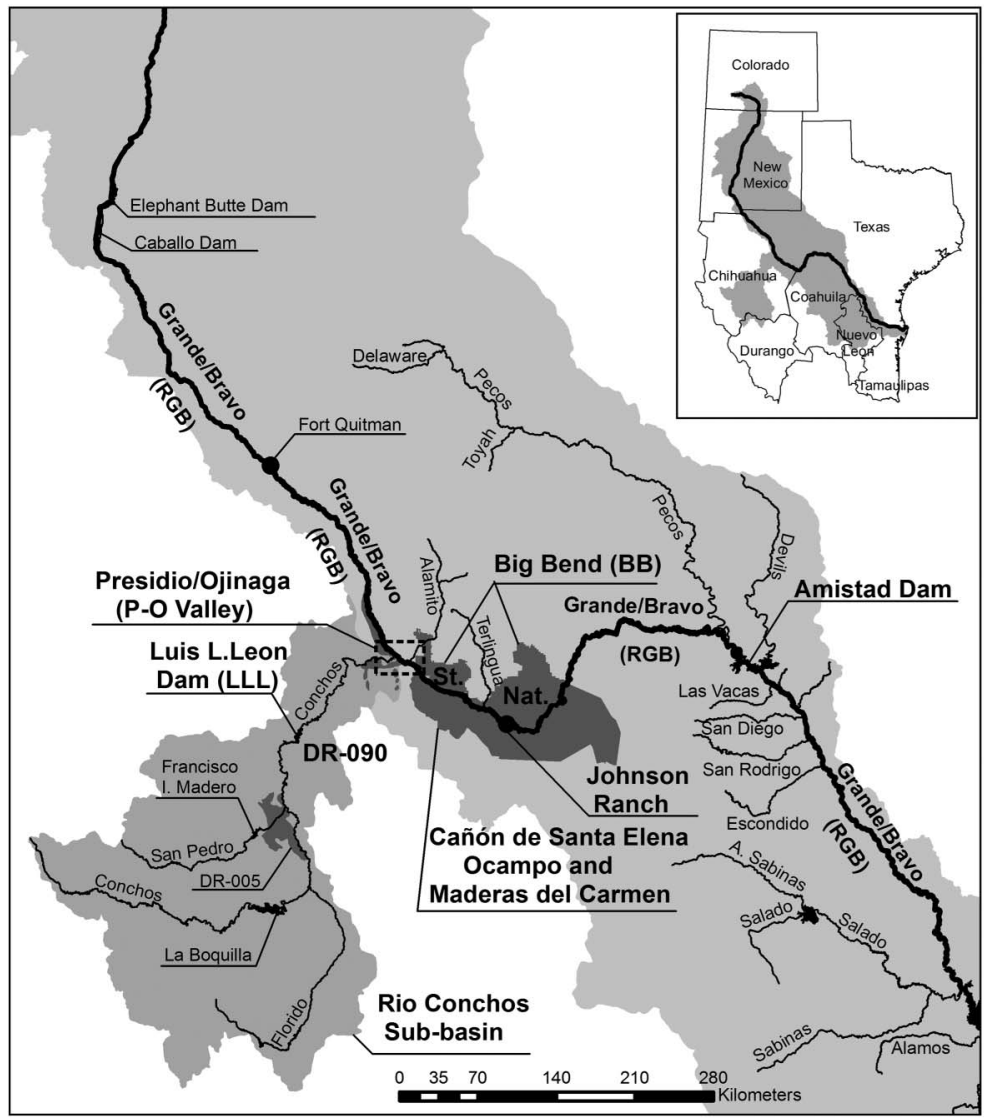

(a)

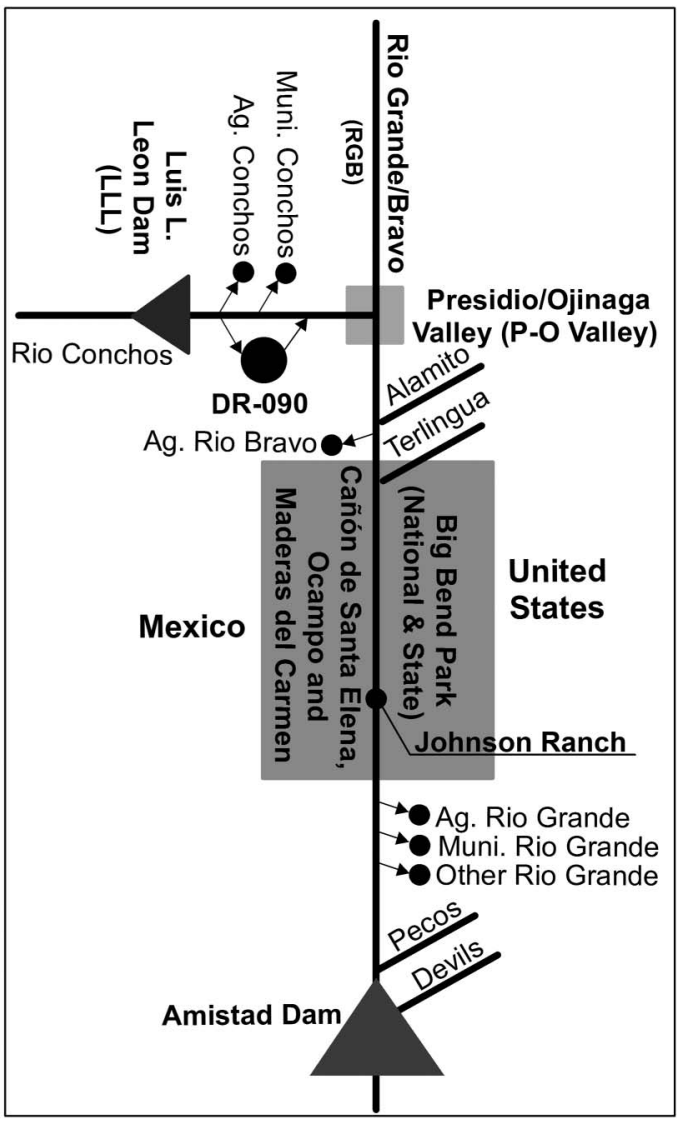

(b)

Fig. 1. Rio Grande/Bravo Basin: (a) Rio Grande Basin; (b) schematic Big Bend Reach

during negotiations for determining strategies to include the environment as an integral part of the water management of the basin. The authors prove that it is possible to manage the system to provide e-flows without increasing flood risk in the P-O Valley, and without affecting human water supply and the international treaty obligations.

\section{Literature Review}

Before the 1990s, water management for environmental purposes was limited to water quality standards and minimum flow requirements. In the last two decades, this has changed toward managing rivers to achieve a more natural flow regime, capturing the seasonal and interannual flow variability, as well as the magnitude, timing, and frequency of different flow conditions (Postel and Richter 2003). Methodologies to determine e-flows can be divided into four types: (1) statistical methods, such as the Tenant or Indicators of Hydrologic Alteration (IHA) methods, these methods analyze the historical hydrology to identify natural flow conditions and prescribe flow recommendations (Tennant 1975, Richter et al. 1996); (2) hydrogeomorphic methods, such as the Near-Census River Assessment and Rehabilitation method, which relates the hydrodynamics of the river with its morphology to design adequate habitat for the environment (Pasternack 2011); (3) instream habitat methods, such as the Instream Flow Incremental method, which relates different flows with habitat changes using predetermined preferences for specific fish species (Bovee 1978); and (4) holistic methods, such as the Building Block method (Tharme and King 1998) or the Benchmark Method (Brizga et al. 2002), these methods use multidisciplinary experts to define a flow regime intended to achieve a particular objective or to determine acceptable degrees of departure from the natural flow regime.

The IHA method is used in this research to propose e-flows because data is available for a period with more desired hydrologic characteristics (IBWC 2011) and it is recommended for planning level analyses (Tharme 2003). In the BB Reach, several studies have analyzed the environmental conditions. Moring (2002) analyzed the stream habitat, fish community, and macroinvertebrates. Schmidt et al. (2003), Dean and Schmidt (2011), and Dean et al. (2011) analyzed the 20th century hydrology, the relation between flows, floods, sediment transport, vegetation, and how these factors affected the evolution of the channel and flood plain. SandovalSolis et al. (2010) estimated the hydrology prior to and after reservoir alteration. Everitt (1998) described the spread of the invasive species of salt cedar (Tamarix spp.). The WWF (2008) summarized the previous studies in a vision and fact sheet- - these studies coincide with the e-flows proposed here.

Models are built to evaluate water management policies; they are a representation of water resource systems. Models for the RGB Basin include: planning models to address drought strategies (Vigerstol 2002), conflict resolution (Tate 2002), water availability (RJBC 2004), and water management scenarios (Sandoval-Solis 2011). Dean and Schmidt (2010) built a one-dimension streamflow discharge model to evaluate the effects of increased vegetation roughness on declining channel capacity in the BB Reach. While in some of these models environmental water management is contemplated for other regions of the RGB Basin (Sandoval-Solis 2011), none 
of them considered the BB Reach. The model built in this research is based on the RGB Basin model (Sandoval-Solis 2011) with two main differences: it is a tailor-made model for the necessities of the BB Reach and is the most updated model. It is the only model that includes the last extended 14-year drought period (1994-2007).

This research proposes a reoperation policy for LLL Reservoir to provide more desired flows in the RGB Basin mainstem, while meeting human and treaty water requirements, and without increasing the flood risk at P-O Valley. Reservoir reoperation policies have been proposed to improve the environment in large (Yang et al. 2007) and small basins (Thompson et al. 2012), in transboundary basins (WB 2004), in multipurpose systems (Bednarek and Hart 2005), considering renewable water sources (Yang et al. 2008), climate change (Thompson et al. 2012), temperature of released water (Olden and Naiman 2010), and to improve the dissolved oxygen in the system (Bednarek and Hart 2005). The main difference with these approaches is the development of an iterative process; e-flows and reservoir reoperation policies are modified interactively to determine the maximum volume of water available for the environment. The method proposed here estimates the physically and legally available volume of water available for the environment given the system constraints.

\section{RGB Basin}

The RGB Basin is a transboundary basin shared by the United States and Mexico [Fig. 1(a)]; it has a drainage basin of $557,722 \mathrm{~km}^{2}$ with an estimated population in 2010 of 10.5 million people (Patiño-Gomez et al. 2007). Important pristine areas in both countries depend on the water in the river for their environmental requirements. The Treaty of 1944 established the water allocation in this region; unfortunately, the environment was not considered in this agreement. As a result, the environment has deteriorated; signs of this deterioration are: progressive channel narrowing (Dean and Schmidt 2010), flow alteration due to reservoir operation (Sandoval-Solis et al. 2010, Dean and Schmidt 2011, Dean et al. 2011), invasion of nonnative species, e.g., salt cedar (Tamarisk spp.) and giant cane (Arundo donax) (Everitt 1998), change from freshwater to estuarine ecosystem (Schmandt 2002) and the almost complete extinction of endemic riverine species, e.g., Rio Grande silvery minnow (Hybognathus amarus) (Bestgen and Platania 1991).

In November 2008, a group of scientists, non-governmental organizations (NGOs), and governmental institutions gathered in a workshop to discuss the environmental problems in the $\mathrm{BB}$ Reach, their possible solutions, gaps in knowledge, and the required research to address them. There were two main outcomes of this workshop: (1) a declaration of a vision for the BB Reach (WWF 2008), which states the required characteristics of the river to preserve, enhance, and restore the riverine ecosystem for the benefit of humans and nature; and (2) an independent scientific committee was created to address gaps in knowledge and design integral solutions based on science and understanding. This paper is part of the discussions and efforts to address integral and scientific solutions for improving the environment in the BB region.

\section{Analysis of River Flow Conditions}

The vision for the BB Reach (WWF 2008) outlines its importance, dependence, and connection with water sources in Mexico, and the qualitative characteristics to support a healthy riverine ecosystem. Some of the desired characteristics are: "A wandering, laterally unstable river channel; a river cross-section form that is relatively wide and shallow; a river with flows that maintain channel capacity" (WWF 2008). Dean and Schmidt (2011) identified these characteristics during their research regarding narrowing of the channel over the last century and the processes responsible for it. They found that prior to 1946 the channel at the BB Reach was in dynamic disequilibrium, wherein the channel was widened during large flood events and subsequently narrowed during the intervening periods at a slower rate than today. Large flood events moved sediments and prevented any substantial accumulation. Since early 1900s small reservoirs were constructed in the RGB Basin. In 1916 the completion of two large reservoirs altered the hydrology of the basin-La Boquilla in the Rio Conchos (in Chihuahua, Mexico) and Elephant Butte in the upper RGB (in New Mexico). Large mean annual flows happened prior to 1920 with a steady decline since 1936-1946 (Dean and Schmidt 2011). In the 1940s, the construction of Caballo Reservoir in the RGB (1938) (in New Mexico) and Francisco I. Madero Reservoir in the San Pedro River (1949) (in Chihuahua, Mexico) modified the flow conditions in the BB Reach, storing the remaining floodwater left in the upper RGB and Rio Conchos subbasin (Sandoval-Solis 2011). As a result, flow conditions changed after 1946, this was evident in the higher rate of channel narrowing; nowadays, the RGB is a narrower river in the BB Reach (Dean and Schmidt 2011). This research considers pre-1946 conditions (lârge floods and lower channel narrowing rate) as a benchmark of a healthier environment compared to recent hydrologic conditions (less frequent large floods and higher channel narrowing rates).

\section{Benchmarks}

Flow conditions were estimated through a probabilistic streamflow analysis at Johnson Ranch gauge station using the IHA method (Sandoval-Solis et al. 2010). Mean daily discharge data was obtained from the International Boundary and Water Commission (IBWC 2011). Johnson Ranch streamflow records were extended until 1901 using a linear regression from data of RGB below Rio Conchos gauge station. Natural cycles of dry (1945-1985, 1993-2007) and wet (1936-1944, 1986-1992) periods have been documented for the BB Reach (Dean and Schmidt 2011). Two periods were analyzed: prior to reservoir alteration period, pre1946, a 30-year period (Jan. 1901-Dec. 1913 and Jan. 1930Dec. 1946); and the postreservoir alteration period, post-1946, with data for 30 years (Jan. 1980-Dec. 2009). For the post-1946 period, the last 30-year period (1980-2009) is selected to analyze the characteristics of the most recent hydrology; it contains a whole hydrologic cycle: the wet period of the 1980s (1984-1993), and the severe and extended drought of the 1990s (1994-2007).

Three flow categories are used as benchmarks to determine the flow characteristics in this reach (Postel and Ritcher 2003): (1) base flows: median value of the mean daily flows for each month aimed to provide adequate habitat, maintain suitable water temperatures, and dissolve oxygen; (2) high flows: streamflows with a peak between the 75th $\left(56 \mathrm{~m}^{3} / \mathrm{s}\right)$ and 95 th $\left(224 \mathrm{~m}^{3} / \mathrm{s}\right)$ percentile of the mean daily flows for the pre-1946 period aimed to prevent riparian vegetation from encroaching into the channel and restore water quality conditions; and (3) floods: streamflows with a peak above the 95 th percentile $\left(224 \mathrm{~m}^{3} / \mathrm{s}\right)$ of the pre-1946 period. This last benchmark is subdivided into two types: (1) small floods between the 95 th percentile $\left(224 \mathrm{~m}^{3} / \mathrm{s}\right)$ and below $1,100 \mathrm{~m}^{3} / \mathrm{s}$, which is a threshold to account for the flood capacity of levees at P-O Valley whose maximum flow capacity is $1,190 \mathrm{~m}^{3} / \mathrm{s}$ (IBWC 1971) and (2) large floods, with a peak above $1,100 \mathrm{~m}^{3} / \mathrm{s}$, these large floods may threaten the safety of the levees and are aimed to shape the 
physical character of river channel and provide longitudinal connectivity of the river. Thresholds have been determined using the pre-1946 period to estimate the flow characteristics of a period with more frequent large floods and slow channel narrowing rates, and compare them with the postalteration period (post-1946). Other hydrologic analyses in the BB Reach (Dean and Schmidt 2011, Dean et al. 2011) used mean annual flow, average flood, and duration as benchmarks for flow conditions for pre-1944 (1936-1944) and post-1944 periods (1945-1985, 1986-1992, 1993-2008).

\section{Prior Reservoir Alteration Conditions}

Fig. 2 shows the median annual hydrograph for the pre-1946 period, its volume is 1,488 million $\mathrm{m}^{3}$ (base flows, 1,128; high flows, 48; small floods, 312), base flows, high flows, and small floods were derived from median daily values. Base flows varied from $11 \mathrm{~m}^{3} / \mathrm{s}$ in April to $98 \mathrm{~m}^{3} / \mathrm{s}$ in September. High flows occurred every year $(T=1)$ in July, August, October, and December; and every $2-3$ years $(2<T<3)$ in May, June, and November. Two small floods occurred every year, one in September (peak flow $=407 \mathrm{~m}^{3} / \mathrm{s}$ ) and another that usually happened in July (peak flow $=405 \mathrm{~m}^{3} / \mathrm{s}$ ), August (peak flow $=$ $396 \mathrm{~m}^{3} / \mathrm{s}$ ), or October (peak flow $=422 \mathrm{~m}^{3} / \mathrm{s}$ ). Fig. 2 shows the case of the small flood in July. The combination of two small floods may have contributed to maintaining the RGB as a wide sandy multithreaded river (Dean and Schmidt 2011, Dean et al. 2011). Sandoval-Solis et al. (2010) explained the methods of calculation and flow conditions for these and other return periods. The pre-1946 hydrograph (Fig. 2) is used as a template for all the hydrographs evaluated here, the peak and duration of small floods and high flows are preserved, the base flow is the benchmark scaled to increase or decrease the environmental hydrograph.

\section{Recent Flow Conditions}

Fig. 3 shows the median annual hydrograph for the post-1946 period, its volume is 571 million $\mathrm{m}^{3}$ (base flows, 450; high flows, 52; small floods, 69). Base flows vary from $8 \mathrm{~m}^{3} / \mathrm{s}$ in April to $24 \mathrm{~m}^{3} / \mathrm{s}$ in September; these values represent half of their respective pre-1946 value for most of the months. High flows occurred every year $(T=1)$ in May, June, July, and August; and every 2-3 years $(2<T<3)$ in March, April, and October. Post-1946's

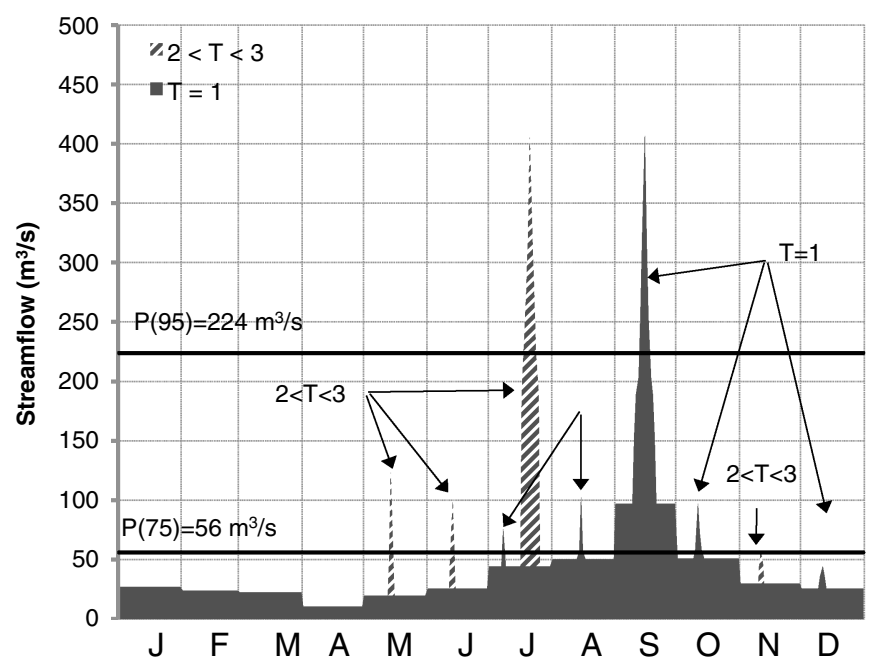

Fig. 2. Flow conditions in the Big Bend Reach at Johnson Ranch, pre-1946

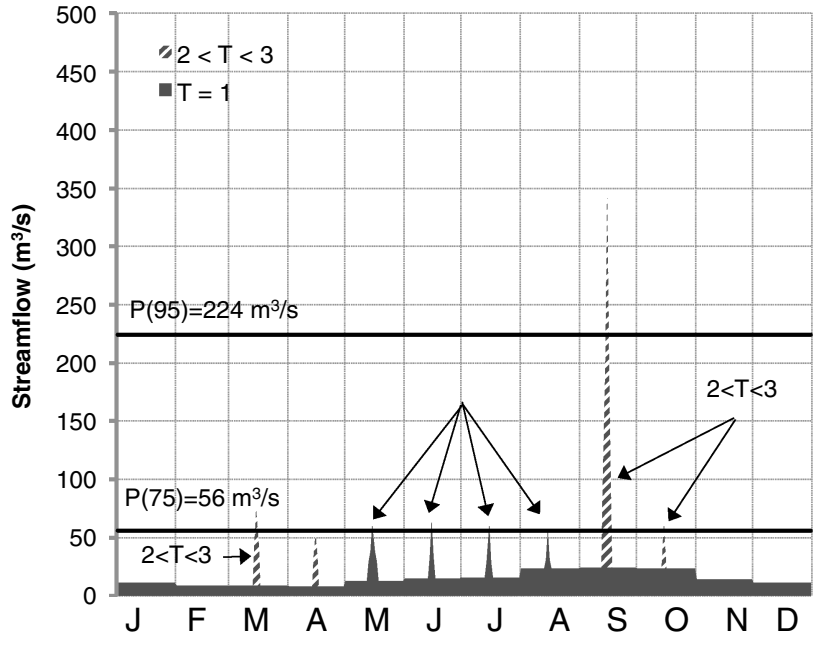

Fig. 3. Flow conditions in the Big Bend Reach at Johnson Ranch, post-1946

high flows occurred earlier in time (May-August), smaller in magnitude and more frequently than pre-1946 conditions; this pattern can be attributed to releases from LLL Reservoir to be prepared for the monsoon season (June-October). Only one small flood occurred every 2-3 years in September (peak flow $=342 \mathrm{~m}^{3} / \mathrm{s}$ ), which is less frequent and smaller than the pre-1946 flows. The reduction in frequency and magnitude of small floods may have contributed to the progressive channel narrowing of the BB Reach.

\section{Water Management in the Big Bend}

All the water that reaches the RGB from tributaries and the gains along the mainstem are allocated to each country according to the 1944 Treaty (IBWC 1944). Each country distributes their treaty allotment and the water in their tributaries according to the regulations of each country. In Texas, water is allocated according to the prior appropriation law (TCEQ 2006), and in Mexico water is allocated according to its water use (CONAGUA 2008b).

\section{Treaty of 1944}

The 1944 Treaty specifies the water allocation for the RGB Basin. In the BB Reach, the United States receives an allocation of: (1) all the waters reaching the RGB from Pecos and Devil Rivers, Alamito and Terlingua Creeks, and Goodenough spring; (2) one-third of the flow reaching the RGB from Rio Conchos; (3) one-half of the gains along the RGB mainstem; and (4) one-half of the water at Fort Quitman from the RGB. In the BB Reach, Mexico has the allocation of: (1) two-thirds of the flow reaching the RGB from Rio Conchos, (2) one-half of the gains along the RGB mainstem, and (3) one-half of the water at Fort Quitman from the RGB (IBWC 1944). Amistad International Reservoir was built to store and manage the water for both countries in the upper RBG Basin; each country has its own storage account. The IBWC is the institution in charge of the execution and compliance of the 1944 Treaty.

\section{U.S. Water Management}

In Texas, the BB Reach is denominated as the upper Rio Grande Basin (from Fort Quitman to Amistad), water is allocated using the prior appropriation rule: "first in time, first in right"; senior water rights are honored before junior water rights. During drought 
periods, the Texas Rio Grande Watermaster Program administered by the Texas Commission on Environmental Quality (TCEQ) may impose reductions in water diversions, allocating water first to municipal and domestic use (TCEQ 2006).

\section{Mexican Water Management}

In Mexico, the National Water Commission (Comisión Nacional del Agua) (CONAGUA) is the federal authority responsible for water management. CONAGUA executes the water management in the tributaries and along the RGB mainstem in Mexico. Water demands are characterized by use; the National Water Law establishes the priority for all water uses (CONAGUA 2008b). Domestic and municipal users have the highest priority and two times their annual water demand must be stored in the reservoirs. Agricultural users are not guaranteed and their allocation depends on the available storage in the respective dam that supplies them. Each October, CONAGUA determines the available reservoir storage after deducting municipal allocations, evaporation, and operation losses. Then, a negotiation between CONAGUA and the irrigation districts sets the agricultural water allocation for the coming water year. On the BB Reach, LLL is managed for two purposes: water supply using the rule aforementioned and for flood control operated at the discretion of CONAGUA. Water released for flood control is important because it reaches the confluence of the RGB and is accounted for treaty obligations.

\section{Water Planning Model for the Big Bend Reach}

The allocation of water in the Big Bend Reach is simulated using the Water Evaluation and Planning System (WEAP) platform (Yates et al. 2005). The water distribution algorithm mimics the allocation of water in the United States, Mexico, and the division of water established in the Treaty of 1944. The hydrologic record considered for this reach is 55 years (Oct. 1955-Sept. 2009). The Big Bend model is a water-planning model that calculates the balance between inflows, change of storage in reservoirs, water demands, and outflows. CONAGUA, TCEQ, and IBWC provided data for inflows, streamflow data, capacities, storage-elevation curves, and evaporation losses in reservoirs (Patiño-Gomez et al. 2007, CONAGUA 2008a, IBWC 2011). Table 1 shows the water demands considered in the model. The performance of the model was evaluated using a 40-year period of analysis (Oct. 1969-Sept. 2009) because during this period, Amistad and LLL Reservoirs were in operation and there are accurate records of water diversions and reservoirs storage (CONAGUA 2008a). The index of agreement (IA) and coefficient of efficiency (CE) were estimated
(Legates and McCabe 1999) for the two reservoirs: LLL $(\mathrm{IA}=0.998, \quad \mathrm{CE}=0.992)$ and Amistad $(\mathrm{IA}=0.993, \mathrm{CE}=$ $0.970)$. These indices were estimated in two gauge stations: Rio Conchos at Ojinaga (IA $=0.994, \mathrm{CE}=0.976)$ and $\mathrm{RGB}$ at Johnson Ranch (IA $=0.9998, \mathrm{CE}=0.991)$, which is the location where the e-flows were determined. These indices show that the model performs very well (Moriasi et al. 2007) compared to the historic records, in all cases the values are larger than 0.95. The simulation process considers the repetition of the 55-year hydrologic record using the recent infrastructure. Monthly use coefficients are used to account for the seasonal variability for each demand (RJBC 2004).

\section{Environmental Water Management}

Water in the $\mathrm{BB}$ region is subject to competing water uses. Water is managed for human consumption, irrigation, meeting international agreements, water demands of downstream users (in Texas, Coahuila, and Tamaulipas), and flood protection. However, the arrangement and size of the infrastructure provides an opportunity to release water from LLL Reservoir in an environmental friendly pattern and capture it in Amistad Reservoir without affecting the objectives mentioned above; i.e., "changing the timing, preserving the long term volume."

The objective of this research is to estimate the maximum volume of water available for the environment. The authors hypothesized that it is possible to manage the system to provide base and high flows, and small floods without affecting the aforementioned uses. The desired water management policy provides e-flows while meeting the following constraints: (1) human water uses below LLL Reservoir are unaffected, (2) releases for environmental purposes should not exceed the levee capacity at P-O Valley [1,190 $\mathrm{m}^{3} / \mathrm{s}$ (IBWC 1971)], (3) flood risk during the monsoon season at P-O Valley is not increased, and (4) the allocation of water under the 1944 Treaty is respected. The last constraint means the water that reaches the RGB from the Rio Conchos is divided according to the treaty and it is on average the same volume that this river has contributed historically to the treaty obligations [1954-2009, (IBWC 2011)] and that was projected when the treaty was signed (Orive-Alba 1945), between 50 and $60 \%$ of the treaty obligations.

If the authors' hypothesis is true, this analysis can provide guidance during discussions regarding water available for the environment, because it quantifies the maximum amount of water that can be transferred from LLL to Amistad Reservoir without affecting human water supply, flood risk at P-O Valley, or the treaty obligations.

Table 1. Performance Criteria and Sustainability Index for Water Users, Historic and Reoperation Scenarios

\begin{tabular}{|c|c|c|c|c|c|c|c|c|c|c|c|c|c|}
\hline \multirow{2}{*}{$\begin{array}{l}\text { Water users, historic and } \\
\text { reoperation scenarios }\end{array}$} & \multirow{2}{*}{$\begin{array}{l}\text { Demand } \\
\left(\text { million } \mathrm{m}^{3}\right)\end{array}$} & \multicolumn{6}{|c|}{ Historic } & \multicolumn{6}{|c|}{ Reoperation } \\
\hline & & $\operatorname{Rel}(\mathrm{V})$ & $\operatorname{Rel}(\mathrm{T})$ & Res & Vul & $\operatorname{Max}$ & S.I. & $\mathrm{R}(\mathrm{V})$ & $\mathrm{R}(\mathrm{t})$ & Res & Vul & Max & S.I. \\
\hline \multicolumn{14}{|l|}{ United States } \\
\hline Mun. Rio Grande & 43.2 & NA & NA & NA & NA & NA & NA & 100 & 100 & 100 & 0 & 0 & 100 \\
\hline Ag. Rio Grande & 0.8 & NA & NA & NA & NA & NA & NA & 65 & 98 & 58 & 4 & 10 & 80 \\
\hline Other Rio Grande & 0.1 & NA & NA & NA & NA & NA & NA & 64 & 95 & 60 & 12 & 25 & 75 \\
\hline \multicolumn{14}{|l|}{ Mexico } \\
\hline Ag. DR 090 & 63.6 & 52 & 86 & 45 & 30 & 89 & 43 & 100 & 100 & 100 & 0 & 0 & 100 \\
\hline Ag. Rio Conchos & 30.0 & 24 & 75 & 11 & 49 & 86 & 27 & 100 & 100 & 100 & 0 & 0 & 100 \\
\hline Ag. Rio Grande & 17.7 & 24 & 75 & 11 & 49 & 86 & 27 & 65 & 99 & 58 & 4 & 8 & 80 \\
\hline Mun. Rio Conchos & 0.3 & 24 & 75 & 11 & 49 & 86 & 27 & 100 & 100 & 100 & 0 & 0 & 100 \\
\hline
\end{tabular}

Note: S.I. = sustainability index; Mun. = municipal; Ag. = agricultural; NA = not available. 


\section{Reservoir Reoperation Policy}

The operation policy proposed for LLL Reservoir considers water supply for the environment while meeting the constraints listed in the previous section. These are the considerations for the proposed policy: (1) LLL provides part of the base flows and the entirety of small floods to the BB Reach, high flows are provided naturally from the rest of the water sources; (2) releases for base flow from LLL takes into account the rest of the water sources (RGB above Ojinaga, Alamito, Terlingua, and gains in Rio Conchos and RGB mainstem); median monthly values for each water source have been estimated and subtracted from the prescribed base flow; (3) releases at LLL are higher in magnitude and duration to meet the e-flows at Johnson Ranch; (4) human water demands are fixed for the simulation period and they represent the current water rights (Table 1), this assumption recognizes that there is a small municipal water demand (less than $1 \%$ of the total water rights) and the agriculture water rights ( $99 \%$ of the total water rights) are not expected to increase in the future (D. Treviño, personal communication, 2010); and (5) inflows to LLL are tracked during two seasons for operational decisions, wet (June-Oct.) and dry (Nov.-May). Drought conditions are considered to exist when inflows during the previous wet or dry season are smaller than 250 or 200 million $\mathrm{m}^{3}$, respectively; or when the storage in LLL is below the drought pool threshold.

A probabilistic analysis of LLL inflows (1949-2009) was carried out to define the drought thresholds; they were determined by comparing the water demands below LLL and the expected inflows considering a $70 \%$-exceedance probability. At the beginning of the dry season (Nov. 1), given that the inflows in the previous wet season are smaller than 250 million $\mathrm{m}^{3}$, there is a $70 \%$ chance that the inflows in the following dry season will be at least 133 million $\mathrm{m}^{3}$. Similarly, at the beginning of the wet season (Jun. 1), given that the inflows in the previous dry season are smaller than 200 million $\mathrm{m}^{3}$, there is a $70 \%$ chance that the inflows in the following wet season will be at least 67 million $\mathrm{m}^{3}$. The sum of these inflows $\left(200\right.$ million $^{3}$ ) is bigger than the annual water demand for human use below LLL considering seepage and evaporation losses, which is 196 million $\mathrm{m}^{3}$. The authors propose a risk of $30 \%$ (70\%-exceedance probability) for the LLL reoperation policy; however, this value may change depending on negotiations and authorities adversity to risk.

The storage in LLL is divided into different zones (see Fig. 4): (1) flood control zone, storage dedicated to manage floods; (2) environmental flows zone, storage dedicated to supply base flows and small floods for the environment, this zone is further divided into base flow and small floods zones; (3) transition zone, storage dedicated to anthropogenic water users, a buffer storage between the drought and environmental flows zone; (4) drought zone, storage dedicated to supply water during drought periods to humans and the environment and (5) dead storage zone, unusable storage. Releases from LLL consist of water for human use and the environment

$$
\text { Releases }_{t}^{\text {LLL }}=\text { Releases }_{t}^{\text {human }}+\text { Releases }_{t}^{\text {env }}
$$

Releases for human use (Releases ${ }_{t}^{\text {human }}, t=1, \ldots, t=12$ ) are secured every month. Releases for the environment consist of base flows $\left(\right.$ Base $\left._{t}, t=1, \ldots, 12\right)$ and small floods $\left(\mathrm{SF}_{t}, t=7, \ldots, 10\right)$

Releases $=$ Base $_{t}+\mathrm{SF}_{t}$

Two types of base flows are proposed: normal and drought. Normal base flows $\left(\right.$ Base $\left._{t}^{\text {normal }}\right)$ are released when LLL storage at the beginning of each month $\left(S_{t-1}^{\mathrm{LLL}}\right)$ is above the base flow storage threshold ( $\left.S^{\text {base flow }}\right)$. Drought flows (Base ${ }_{t}^{\text {drought }}$ ) are released when the storage at the beginning of the month $\left(S_{t-1}^{\mathrm{LLL}}\right)$ is below the drought storage threshold ( $\left.S^{\text {drought }}\right)$ or for the whole season when the inflows in the previous wet $\left(I_{\text {season-1 }}^{\mathrm{Wet}}\right)$ or dry

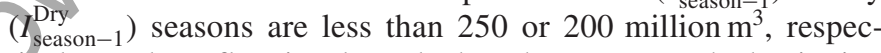
tively. No base flow is released when the storage at the beginning of the month is in the transition zone ( $\left.S^{\text {base flow }}>S_{t-1}^{\text {LLL }}>S^{\text {drought }}\right)$. Base flows $\left(\right.$ Base $\left._{t}, t=1, \ldots, 12\right)$ are released from LLL according to the rule

$$
\text { Base }_{t}=\left\{\begin{array}{lll}
\text { Base }_{t}^{\text {Normal }} & \text { if } S_{t-1}^{\text {LLL }}>S^{\text {Base Flow }} & \text { for } t=1, \ldots, 12 \\
\text { Base }_{\text {Drought }} & \text { if } S^{\text {Drought }}>S_{t-1}^{\text {LLL }}>S^{\text {Dead }} & \text { for } t=1, \ldots, 12 \\
\text { Base }_{t}^{\text {Drought }} & \text { if } I_{\text {Season-1 }}^{\text {Wet }}<250 & \text { for } t=11,12,1,2, \ldots, 6 \\
\text { Base }_{t}^{\text {Drought }} & \text { if } I_{\text {Season-1 }}^{\text {Dry }}<200 & \text { for } t=7, \ldots, 10 \\
0 & \text { if } S^{\text {Base Flow }}>S_{t-1}^{\text {LLL }}>S^{\text {Drought }} & \text { for } t=1, \ldots, 12
\end{array}\right.
$$

Small floods are released when the LLL storage at the beginning of the month $\left(S_{t-1}^{\mathrm{LLL}}\right)$ is above the small flood threshold $\left(S^{\mathrm{flood}}\right)$. No small floods are released if the storage at the beginning of the month $\left(S_{t-1}^{\mathrm{LLL}}\right)$ is below the small flood threshold ( $\left.S^{\text {small flood }}\right)$ or if the inflows in the previous dry season $\left(I_{\text {Season-1 }}^{\text {Dry }}\right)$ are smaller than 200 million $\mathrm{m}^{3}$. Small floods $\left(\mathrm{SF}_{t}, t=7, \ldots, 10\right)$ are released from LLL during July to October according to the rule

$$
\mathrm{SF}_{t}= \begin{cases}\text { Release }_{t}^{\text {Flood }} & \text { if } S_{t-1}^{\mathrm{LLL}}>S^{\text {Small Flood }} \\ 0 & \text { if } S_{t-1}^{\mathrm{LLL}}<S^{\text {Small Flood }} \\ 0 & \text { if } I_{\text {Season-1 }}^{\text {Dry }}<200\end{cases}
$$

\section{Simulation Process}

An iterative simulation process was used to determine the maximum volume of water available for the environment. First, an environmental hydrograph is proposed, e.g., a hydrograph of 900 million $\mathrm{m}^{3}$ /year (base flows, 524; high flows, 41; small floods, $335)$. Second, a set of storage thresholds ( $S^{\text {flood control }}, S^{\text {small flood, }}$ $\left.S^{\text {base flow }}, S^{\text {drought }}\right)$ and a drought base flow (Base $\left.{ }_{t}^{\text {drought }}\right)$ are proposed and entered in the model. Third, the model is run and results are analyzed. If results meet the constraints specified for the system, as aforementioned, the model is considered a feasible solution, otherwise the results are discarded. Several annual environmental hydrographs $\left(1,300,1,250, \ldots, 650,600\right.$ million $\mathrm{m}^{3} /$ year $)$ were 


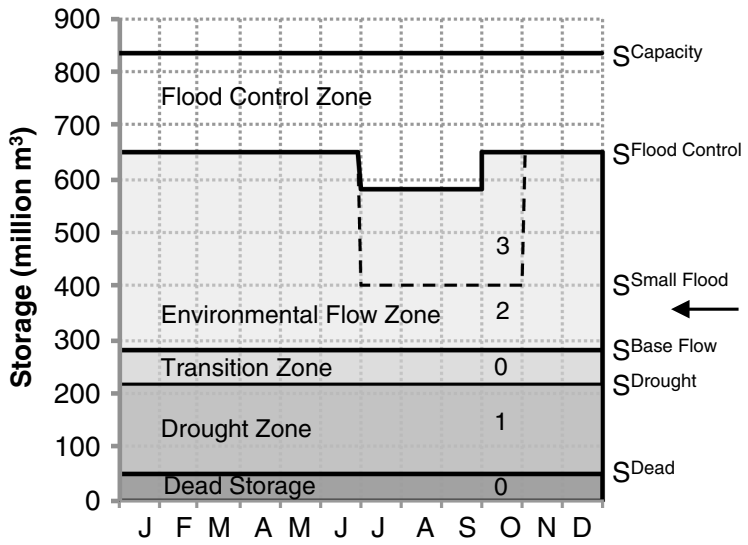

Fig. 4. Storage zones and thresholds for Luis L. Leon reservoir (zone 0: base $_{t}=0$; zone 1: base $_{t}=$ base $_{t}^{\text {drought }}$; zone 2: base $_{t}=$ base $_{t}^{\text {normal }}, \mathrm{SF}_{t}=0$; zone 3: base $_{t}=$ base $_{t}^{\text {normal }}, \mathrm{SF}_{t}=$ release $\mathrm{flood}_{t}^{\text {flo }}$, base $_{t}=$ base $_{t}^{\text {drought }}$ at all times if $I_{\text {Season-1 }}^{\text {Wet }}<250$ or $I_{\text {Season- } 1}^{\text {Dry }}<250$, $\mathrm{SF}_{t}=0$ at all times if $I_{\text {Season-1 }}^{\text {wet }}<250$ or $I_{\text {Season-1 }}^{\text {Wet }}$, units: million $\mathrm{m}^{3}$; wet season: June-Oct, dry season: Nov.-May)

evaluated using the template of the pre-1946 conditions. The peak and duration high flows are preserved in each annual hydrograph as suggested by Postel and Richter (2003), the peak of small floods is reduced to $375 \mathrm{~m}^{3} / \mathrm{s}$ according to the suggestion of Big Bend National Park hydrologist (J. Bennett, personal communication, 2011). Base flow is the benchmark used to increase or decrease the annual environmental hydrograph. The feasible solution that supplied the largest flow through the Big Bend Reach is the policy that provides the maximum water for the environment.

\section{Results}

Maximum Hydrograph for the Environment

According to the analysis reported here, the maximum amount of water that can be supplied to the BB Reach at Johnson Ranch without affecting other water users or treaty obligations, or increasing the flood risk in Ojinaga/Presidio is 982 million $\mathrm{m}^{3} /$ year (base flow, 624; high flows, 36; small floods, 322) (see Fig. 5

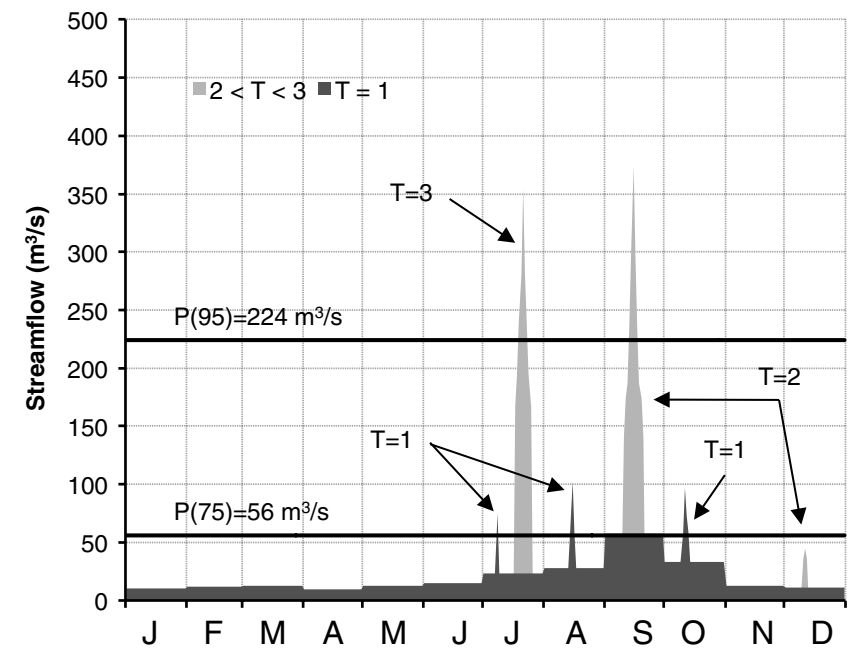

Fig. 5. Hydrograph that supplies the maximum amount water through the Big Bend Reach and Table 2). Base flows vary from $9 \mathrm{~m}^{3} / \mathrm{s}$ in April to $56 \mathrm{~m}^{3} / \mathrm{s}$ in September following the same pattern as the pre-1946 base flow conditions. High flows occurred every year $(T<1.5)$ in July, August, and October; and every 2 years $(T=2)$ in December. One small flood occurs every 2 years in either September or October (peak flow $=374 \mathrm{~m}^{3} / \mathrm{s}$ ) and every 3 years in either July or August (peak flow $=355 \mathrm{~m}^{3} / \mathrm{s}$ ). The drought base flows released are 44 million $\mathrm{m}^{3} /$ year; these drought base flows have the same distribution as the normal base flows. These results represent an improvement from post-1946 conditions (Fig. 3), base flows are larger and follow the same pattern as the pre-1946 conditions, high flows and small floods occur more frequently at the right time and water can be released in drought periods. The average at Johnson Ranch, which is 1,004 million $\mathrm{m}^{3}$ /year (19552009), this means the proposed policy preserves the long-term volume while adjusting the timing of the deliveries in an environmental pattern. Table 2 shows the set of storage thresholds that combined with the reservoir reoperation policy make possible the delivery of the hydrograph in Fig. 5.

Water supply system performance for stakeholders is evaluated using the sustainability index (SI) for water resources management. The SI is a summary index that integrates results of several performance criteria using a geometric average, its scale varies from 0 to 1 with 1 being the most desirable. The performance criteria selected to evaluate stakeholders are: reliability (time and volume), vulnerability, resilience, and maximum deficit. These criteria have been selected because they represent the desired characteristics for the stakeholders water supply: a reliable water supply in time and volume that recovers fast from deficits (high resilience), when deficit happen the average and worst case deficit should be small (low vulnerability and maximum deficit) (Sandoval-Solis et al. 2011). The SI $\left(\mathrm{SI}^{i}\right)$ for the $i$ th water user is

$$
\mathrm{SI}^{i}=\left[\operatorname{Rel}_{\text {Time }}^{i} * \operatorname{Rel}_{\mathrm{Vol}}^{i} * \operatorname{Resil}^{i} *\left(1-\operatorname{vuln}^{i}\right) *\left(1-\operatorname{Max}^{i} \operatorname{Def}^{i}\right)\right]^{1 / 5}
$$$$
\mathrm{SI}^{i}=\left[\operatorname{Rel}_{\text {Time }}^{i} * \operatorname{Rel}_{\mathrm{Vol}}^{i} * \operatorname{Resil}^{i} *\left(1-\operatorname{vuln}^{i}\right) *\left(1-\operatorname{Max}_{\operatorname{Def}}\right)^{i}\right]^{1 / 5}
$$

Table 1 shows the SI for all water users. Two scenarios are compared, the historic scenario (Historic) and the reservoir reoperation scenario (Reoperation). The results show that all the water demands supplied from LLL Reservoir (Ag. DR-090, Ag. Rio Conchos, and Mun. Rio Conchos) have a SI of $100 \%$, meaning that their water demands are fully supplied during the whole period [ $100 \%$ reliability (time and volume) and resilience; $0 \%$ vulnerability and maximum deficit]. Also, U.S. Municipal Rio Grande is fully supplied because it has the highest priority, the remaining water users have a SI less than $100 \%$ but greater than $75 \%$. These results contrast with the Historic scenario SI values, which are lower than $43 \%$. In summary, the reservoir reoperation policy does not affect the water supply of any stakeholder in the region; on the contrary, it improves the water supply compared with the Historic scenario.

The Rio Conchos is one of the six tributaries whose waters contribute to the delivery of treaty obligations from Mexico to the United States. When the Treaty of 1944 was signed, the average annual outflow from this river was considered 770 million $\mathrm{m}^{3} /$ year, $59 \%$ of the treaty obligations (Orive-Alba 1945). The historic average and median outflow for the Rio Conchos from 1955 to 2009 are 782 and 661 million $\mathrm{m}^{3}$ /year; these values represent 60 and $51 \%$ of the treaty obligations, respectively. Similarly, the average and median outflow for the Rio Conchos in the Reoperation scenario are 732 and 609 million $\mathrm{m}^{3}$ /year; these values represent 56 and $47 \%$ of the treaty obligations, respectively. volume of the hydrograph shown in Fig. 5 is similar to the historic 
Table 2. Maximum Environmental Hydrograph and Storage Levels for the Policy Proposed

\begin{tabular}{|c|c|c|c|c|c|c|c|c|c|c|c|c|c|c|}
\hline Flow condition & Value & Unit & Jan. & Feb. & Mar. & Apr. & May & Jun. & Jul. & Aug. & Sept. & Oct. & Nov. & Dec. \\
\hline \multicolumn{15}{|l|}{ Maximum hydrograph } \\
\hline Base flow & Median & $\mathrm{m}^{3} / \mathrm{s}$ & 10 & 12 & 13 & 9 & 12 & 15 & 23 & 28 & 57 & 33 & 12 & 11 \\
\hline \multirow[t]{3}{*}{ High flows } & Peak & $\mathrm{m}^{3} / \mathrm{s}$ & - & - & - & - & - & - & 75 & 102 & - & 97 & 58 & 45 \\
\hline & Duration & days & - & - & - & - & - & - & 1 & 3 & - & 4 & 3 & 3 \\
\hline & Return period & years & - & - & - & - & - & - & 1.4 & 1.3 & - & 1.1 & - & 2.0 \\
\hline \multirow[t]{3}{*}{ Small floods } & Peak & $\mathrm{m}^{3} / \mathrm{s}$ & - & - & - & - & - & 355 & - & - & 374 & - & - & - \\
\hline & Duration & days & - & - & - & - & - & 9 & - & - & 11 & - & - & - \\
\hline & Return period & years & - & - & - & - & - & 3 & - & - & 2 & - & - & - \\
\hline \multicolumn{15}{|l|}{ Reservoir reoperation } \\
\hline \multirow[t]{2}{*}{ Flood control } & $S^{\text {capacity }}$ & MCM & 832 & 832 & 832 & 832 & 832 & 832 & 832 & 832 & 832 & 832 & 832 & 832 \\
\hline & $S^{\text {Flood control }}$ & MCM & 650 & 650 & 650 & 650 & 650 & 650 & 580 & 580 & 580 & 650 & 650 & 650 \\
\hline \multirow[t]{2}{*}{ Environmental flow } & $S^{\text {Small flood }}$ & $\mathrm{MCM}$ & - & - & - & - & - & - & 406 & 406 & 288 & 288 & - & - \\
\hline & $S^{\text {Base flow }}$ & MCM & 283 & 283 & 283 & 283 & 283 & 283 & 283 & 283 & 283 & 283 & 283 & 283 \\
\hline \multirow[t]{2}{*}{ Drought zone } & $S^{\text {Drought }}$ & MCM & 217 & 217 & 217 & 217 & 217 & 217 & 217 & 217 & 217 & 217 & 217 & 217 \\
\hline & $S^{\text {Dead }}$ & MCM & 50 & 50 & 50 & 50 & 50 & 50 & 50 & 50 & 50 & 50 & 50 & 50 \\
\hline
\end{tabular}

Note: $\mathrm{MCM}=$ million $\mathrm{m}^{3}$.

Because the average and median annual outflow have a similar value and distribution (Fig. 6) with the historic and treaty's signature values, these results show that the reservoir reoperation policy does not harm the delivery of treaty obligations from Mexico to the United States. Thus, the Rio Conchos will continue to contribute about the same amount of water to the treaty obligations, but with improved environmental conditions and human water supply.

The safety of the O-P Valley from floods is considered in the Reoperation scenario. Until 2009, 15 major flood events occurred in this valley, as shown in Table 3 (IBWC 1971, 2011). In 1971, the levee capacity at Ojinaga/Presidio was upgraded for a 25-year return period flood estimated to be $1,190 \mathrm{~m}^{3} / \mathrm{s}$ (IBWC 1971); however, four floods occurred after the levees were upgraded. In all of the cases from 1971 to 2009, daily streamflow values were close to or larger than the levee capacity; monthly values for these events are larger than 550 million $\mathrm{m}^{3}$ (Sept. 1978). This monthly value is used as a threshold to identify months that are likely to experience flood events. In the Historic scenario 10 months higher than 550 million $\mathrm{m}^{3}$ occur representing a flood risk of $18.2 \%$ (5.5-year return period), while in the Reoperation scenario only seven events occur representing a flood risk of 12.7\% (8-year return period). These results show that the proposed policy reduces the frequency of months when floods are likely to occur.

The volume of water conveyed in each of the seven floods after 1955 has been analyzed and compared with the Historic scenario at

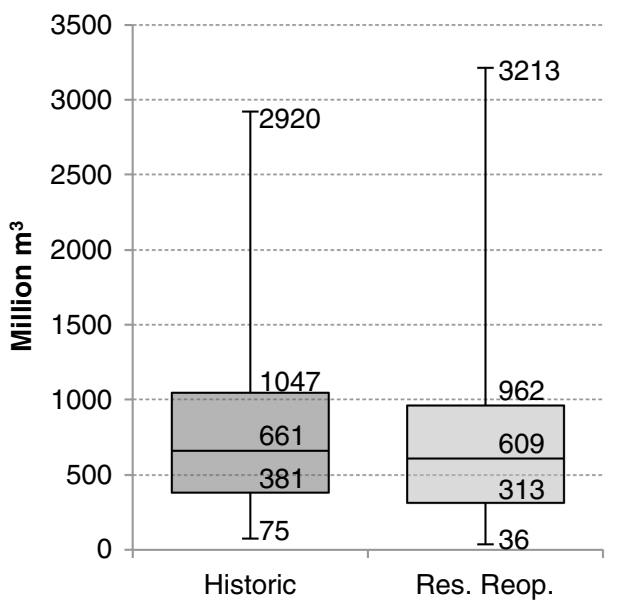

Fig. 6. Annual outflow distribution of Rio Conchos at Ojinaga
Ojinaga. In five flood events (1958, 1966, 1978, 1990, and 2008) the volume of water passed through O-P Valley is smaller than in the historic values, $18 \%$ less volume on average. On the contrary, in two flood events, 1991 and 1968, results from the Reoperation scenario are about $20 \%$ larger than the historic events. These mixed results show that the Reoperation policy has the potential to reduce flood damages; however, a more refined time scale reservoir operation-flooding model is required to properly address this issue. The authors acknowledge that results regarding flood risk are a coarse estimation; the purpose this analysis is to highlight the potential opportunity to improve flood risk management through a reservoir reoperation policy, such as the one proposed.

\section{Tradeoffs among Flow Conditions}

Fig. 7 shows the tradeoffs between base flows (left $y$-axis) and small floods (right $y$-axis, inverse) for a set of different feasible solutions. These two variables are inversely correlated, as the base flow increases, the frequency of small floods decreases (the return period increases, $T=1$ /frequency). For instance, an annual base flow of 300 million $\mathrm{m}^{3}$ allows the delivery of small floods every year $(T=1.2)$ in Sept.-Oct. and every 2 years $(T=2)$ in JulyAugust. In contrast, an annual base flow of 624 million $\mathrm{m}^{3}$, as the maximum hydrograph, allows delivery of small floods every 2 years $(T=2)$ in Sept.-Oct. and every 3 years $(T=3.2)$ in July-August.

Fig. 7 shows the different combinations of environmental flows that can be managed and their consequences. Providing more frequent small floods may help to preserve the width of the river

Table 3. Historic Flows in the Big Bend Reach

\begin{tabular}{|c|c|c|c|c|c|}
\hline Year & Month & $\begin{array}{c}\text { Peak flow } \\
\left(\mathrm{m}^{3} / \mathrm{s}\right)\end{array}$ & Year & Month & $\begin{array}{c}\text { Peak flow } \\
\left(\mathrm{m}^{3} / \mathrm{s}\right)\end{array}$ \\
\hline $1829^{a}$ & NA & NA & $1944^{\mathrm{a}}$ & September & 1,243 \\
\hline $1868^{a}$ & NA & NA & $1958^{\mathrm{a}}$ & October & 1,538 \\
\hline $1904^{\mathrm{a}}$ & September & 4,587 & $1966^{\mathrm{a}}$ & September & 527 \\
\hline $1917^{\mathrm{a}}$ & September & 3,964 & $1968^{\mathrm{a}}$ & September & 467 \\
\hline $1932^{\mathrm{a}}$ & October & 3,002 & $1978^{b}$ & September & 1,850 \\
\hline $1938^{\mathrm{a}}$ & September & 1,928 & $1991^{b}$ & September & 1,030 \\
\hline $1941^{\mathrm{a}}$ & May & 892 & $2008^{b}$ & September & 1,490 \\
\hline $1942^{\mathrm{a}}$ & September & 1,682 & & & \\
\hline
\end{tabular}

Note: NA = not available.

${ }^{\mathrm{a}}$ IBWC (1971).

${ }^{\mathrm{b}}$ IBWC (2011). 


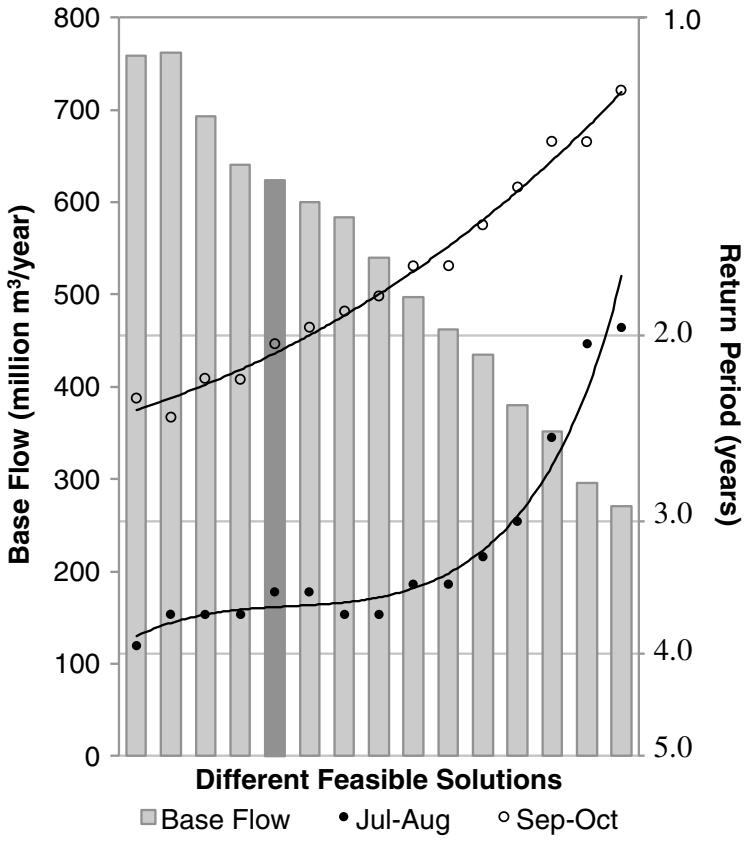

Fig. 7. Tradeoffs between base flows and return periods for small floods (vertical bars are values of base flow, solid dots are July-August flood flows, and open dots are September-October flood flows)

channel; however, it may compromise the subsistence of the aquatic ecosystem because of low base flows all year long. On the contrary, reoperating LLL for high base flows may provide benefits for the aquatic ecosystem, but channel narrowing may resume due to the low frequency in small floods. This figure shows that while there is a hydrograph that can provide the maximum amount of water for environmental purposes (darker column in Fig. 7), there are several combinations that can provide a wide range of base flows and small floods. These combinations should be analyzed by scientists and decision makers to determine which combination(s) can support the aquatic ecosystem with water all year around (through base flows), while at the same time keeping the channel open (through frequent small floods). Detailed research on the aquatic ecosystem and the geomorphology dynamics of the river are necessary to determine the combination that would be most beneficial for the environment.

\section{Conclusions}

The authors' hypothesis was confirmed through this research-it is possible to manage water in the $\mathrm{BB}$ Reach to provide e-flows without affecting municipal, agricultural, or treaty obligations and without increasing the flood risk in the P-O Valley: "changing the timing, preserving the long term volume." The reservoir reoperation policy increases the overall water supply for human water users in the United States and Mexico. Moreover, this policy reduces the frequency of months where floods are likely to occur. Under the proposed policy the outflow distribution for the Rio Conchos is similar to the historic and treaty's signature conditions, meaning that about the same amount of water in the same time will be delivered to meet the treaty obligations from Mexico to the United States. Furthermore, water released from LLL Reservoir are recaptured in Amistad Reservoir, where it is stored and redistributed without affecting water users downstream.

The maximum annual amount of water that can be managed and delivered for e-flows in the Big Bend Reach at Johnson
Ranch is 982 million $\mathrm{m}^{3}$, which is $66 \%$ of the prereservoir alteration conditions $\left(1,488\right.$ million $\left.\mathrm{m}^{3}\right)$ and $98 \%$ of the historic average $\left(1,004\right.$ million $\left.\mathrm{m}^{3}\right)$. Base flows delivered are 624 million $\mathrm{m}^{3} /$ year, which represent $55 \%$ of the pre-1946 conditions $\left(1,129\right.$ million $\left.\mathrm{m}^{3}\right)$, these base flows mimic the prealteration conditions. High flows and small floods are likely to occur with the same magnitude and similar frequency as in the pre-1946 conditions. The main difference is in the frequency for Sept.-Oct. small floods, in the reservoir reoperation policy they will occur every 2 years while in the pre-1946 conditions that used to happen every year. Besides the maximum annual hydrograph, other feasible solutions were found with different combinations of base flows and frequencies of small floods. In fact, there is an inverse relationship between these two benchmarks-an increase in base flow volume represents a decrease in small floods frequency and vice versa. These feasible solutions will help to understand the expected frequency of small floods given a particular base flow in the river.

\section{Limitations}

First, results from the reservoir reoperation policy are obtained assuming a repetition of the historic hydrology in this region, the authors acknowledge the potential nonstationarity of the hydrology due to climate change. Second, the annual hydrographs presented in this paper are a simplification of daily processesfurther refinement in time scale may be necessary. Third, pilot e-flows and monitoring are necessary to evaluate the impact of e-flows in sediment transport and riverine ecosystem. Fourth, it is necessary to evaluate sediment transportation; moving sediment from the $\mathrm{BB}$ Reach to Amistad may reduce the conservation storage in this reservoir. Fifth, flood risk results are a coarse approximation of the overall performance; detailed flood analysis and modeling is required to properly address the flood risk in $\mathrm{P}-\mathrm{O}$ Valley, including the operation of reservoir upstream LLL. Sixth, water quality issues are necessary to address in the BB Reach, primary concerns include high bacteria levels, salinity, and nutrients (Sandoval-Solis 2011). Suggestions for future research include water quality, hydrologic, and flood modeling; climate change analysis, sediment transport, and estimation of gains and conveyance losses.

\section{Acknowledgments}

The authors thank the National Council of Science and Technology of Mexico CONACYT for the financial support provided to the first author. Special thanks are provided to all the people involved in the scientific committee for the Big Bend, especially to Dr. John (Jack) C. Schmidt who reviewed and improved the content of this paper.

\section{References}

Bednarek, A. T., and Hart, D. D. (2005). "Modifying dam operations to restore rivers: Ecological responses to Tennessee River dam mitigation." J. Ecol. Appl., 15(3), 997-1008.

Bestgen, K. R., and Platania, S. P. (1991). "Status and conservation of the Rio Grande silvery minnow, Hybognathus amarus." Southwestern Naturalist, 36(2), 225-232.

Bovee, K. D. (1978). "The incremental methods of assessing habitat potential for coolwater species, with management implications." Selected coolwater fishes of North America, R. L. Kendall, ed., American Fisheries Society, Bethesda, MD, 340-346. 
Brizga, S. O., et al. (2002). "Benchmarking, a 'top-down' methodology for assessing environmental flows for rivers." Proc., Int. Conf. on Environmental Flows for Rivers, Southern Waters Consulting, Cape Town, South Africa.

Comisión Nacional del Agua (CONAGUA). (2008a). "Acuerdo por el que se da a conocer el resultado de los estudios de disponibilidad media anual de las aguas superficiales en la cuenca del Rio Bravo" Diario Oficial de la Federación. 29/Sep/08. México D.F. (in Spanish).

Comisión Nacional del Agua (CONAGUA). (2008b). "Ley de Aguas Nacionales y su Reglamento.” México, D.F. ISBN 968-817-626-5 (in Spanish).

Dean, D. J., and Schmidt, J. C. (2010). "Monitoring geomorphic response to exotic plant removal on the Rio Grande in the Big Bend region: An initial assessment." Task Agree. No. J7130080065. Final Rep. Coop. Agreement between the National Park Service, Big Bend National Park, and Utah State Univ., Logan, UT.

Dean, D. J., and Schmidt, J. C. (2011). "The role of feedback mechanisms in historic channel changes of the lower Rio Grande in the Big Bend region." J. Geomorpho., 126(3-4), 333-349.

Dean, D. J., Scott, M. L., Shafroth, P. B., and Schmidt, J. C. (2011). "Stratigraphic, sedimentologic, and dendrogeomorphic analyses of rapid floodplain formation along the Rio Grande in Big Bend National Park, Texas." Geol. Soc. Am. Bull., 123(9-10), 1908-1925.

Everitt, B. L. (1998). "Chronology of the spread of tamarisk in the central Rio Grande." Wetlands, 18(4), 658-668.

International Boundary, and Water Commission (IBWC). (1944). Treaty between the United States and Mexico. Utilization of waters of the Colorado and Tijuana Rivers and of the Rio Grande, U.S. Department of State, Washington, DC.

International Boundary, and Water Commission (IBWC). (1971). "Proposed flood control project Rio Grande, Presidio Valley, Texas." Report as part of an international coordinated flood control plan with Mexico for the Presidio-Ojinaga Valley, U.S. Department of State, Washington, DC.

International Boundary, and Water Commission (IBWC). (2011). "Rio Grande historical mean daily discharge data." $\langle$ http://www.ibwc.state .gov/Water_Data/histflo1.htm〉 (Dec. 31, 2009).

Legates, D. R., and McCabe, G. J. (1999). "Evaluating the use of "goodness-of-fit" measures in hydrologic and hydroclimatic model validation." Water Resour. Res., 35(1), 233-241.

Loucks, D. P. (1997). "Quantifying trends in system sustainability?" Hydrol. Sci. J., 42(4), 513-530.

Moriasi, D. N., Arnold, J. G., Van Liew, M. W., Bingner, R. L., Harmel, R. D., and Veith, T. L. (2007). "Model evaluation guidelines for systematic quantification of accuracy in watershed simulations." Trans. $A S A B, 50(3), 885-900$.

Moring, J. B. (2002). "Baseline assessment of instream and riparian-zone biological resources on the Rio Grande in and near Big Bend National Park, Texas." Water Resour. Invest. Rep. 02-4106, U.S. Geological Survey, Austin, TX.

Obama, B., and Calderón, F. (2010). "Joint statement from President Barack Obama and President Felipe Calderón."〈http://www.whitehouse.gov/ the-press-office/joint-statement-president-barack-obama-and-president -felipe-calder-n〉 (Dec. 2, 2013).

Olden, J. D., and Naiman, R. J. (2010). "Incorporating thermal regimes into environmental flows assessments: Modifying dam operations to restore freshwater ecosystem integrity." J. Freshwater Biol., 1(55), 86-107.

Orive-Alba, A. (1945). "Informe técnico sobre el tratado internacional de aguas presentado ante el H. Senado mexicano." Comisión Nacional de Irrigación. México D.F. (in Spanish).

Pasternack, G. B. (2011). "2D modeling and ecohydraulic analysis." Createspace, Seattle.

Patiño-Gomez, C., McKinney, D. C., and Maidment, D. R. (2007). "Sharing water resources data in the bi-national Rio Grande/Bravo Basin." J. Water Resour. Plann. Manage., 10.1061/(ASCE)07339496(2007)133:5(416), 416-426.
Postel, A., and Richter, B. (2003). Rivers for life. Managing water for people and nature, Island Press, Washington, DC.

Richter, B. D., Baumgartner, J. V., Powell, J., and Braun, D. P. (1996). "A method for assessing hydrological alteration within ecosystems." J. Conserv. Biol., 10(4), 1163-1174.

R. J. Brandes Co. (RJBC). (2004). "Water availability modeling for the Río Grande Basin: Water availability assessment. Final report.” Texas Commission on Environmental Quality, Austin, TX.

Sandoval-Solis, S. (2011). "Water planning and management for large scale river basins. Case of study: Rio Grande/Rio Bravo transboundary basin." Ph.D. dissertation, Univ. of Texas at Austin, Austin, TX.

Sandoval-Solis, S., McKinney, D. C., and Loucks, D. P. (2011). "Sustainability index for water resources planning and management." J. Water Resour. Plann. Manage., 10.1061/(ASCE)WR.1943-5452.0000134, 381-390.

Sandoval-Solis, S., Reith, B., and McKinney, D. C. (2010). "Hydrologic analysis before and after reservoir alteration at the Big Bend Reach, Rio Grande/Rio Bravo." CRWR Online Rep. 10-06, 〈http://www.crwr .utexas.edu/reports/2010/rpt10-6.shtml (Nov. 5, 2012).

Schmandt, J. (2002). "Bi-national water issues in the Rio Grande/Rio Bravo Basin.” J. Water Policy, 4(2), 137-155.

Schmidt, J. C., Everitt, B. L., and Richard, G. A. (2003). "Hydrology and geomorphology of the Rio Grande and implications for river rehabilitation." Aquatic fauna of the northern Chihuahuan Desert, G. P. Garrett, and N. L. Allan, eds., Spec. Publ. No. 46, Sul Ross State Univ., Alpine, TX.

Tate, D. E. (2002). "Bringing technology to the table: Computer modeling, dispute resolution and the Rio Grande." M.S. thesis, Univ. of Texas at Austin, Austin, TX.

Tennant, D. L. (1975). "Instream flow regimes for fish, wildlife, recreation and related environmental resources." J. Fisheries, 1(4), 6-10.

Texas Commission on Environmental Quality (TCEQ). (2006). "Allocation and distribution of waters: Distribution of available waters-Upper Rio Grande and all Rio Grande tributaries." Chapter 303, Texas Administrative Code Title 30: Environmental quality, Austin, TX.

Tharme, R. E. (2003). "A global perspective on environmental flow assessment; emerging trends in the development and application of environmental flow methodologies for rivers." J. River Res. Appl., 19(5-6), 397-441.

Tharme, R. E., and King, J. M. (1998). "Development of the building block methodology for instream flow assessments, and supporting research on the effects of different magnitude flows on riverine ecosystems." Water Res. Com. Rep. No. 576/1/98, Cape Town, South Africa.

Thompson, L., Escobar, M., Mosser, C. M., Purkey, D. R., Yates, D., and Moyle, P. B. (2012). "Water management adaptations to prevent loss of spring-run Chinook salmon in California under climate change." J. Water Resour. Plann. Manage., 10.1061/(ASCE)WR.1943-5452 $.0000194,465-478$.

Vigerstol, K. (2002). "Drought management in Mexico's Rio Bravo Basin." M.S. thesis, Univ. of Washington, Seattle.

World Bank (WB). (2004). "Modeled observations on development scenarios in the lower Mekong Basin." Rep. to the Mekong River Commission, The World Bank, Washington, DC.

World Wildlife Fund (WWF). (2008). A vision for the Big Bend Reach of the Rio Grande/Rio Bravo, Utah State University, Logan, UT.

Yang, W., Sun, D., and Yang, Z. (2008). "A simulation framework for water allocation to meet the environmental requirements of urban rivers: Model development and a case study for the Liming River in Daqing City, China.” J. Environ. Fluid Mech., 8(4), 333-347.

Yang, Z., Cui, B., and Chen, H. (2007). "A holistic approach for evaluating ecological water allocation in the Yellow River Basin of China." J. Front. Environ. Sci. Eng. China, 1(1), 99-106.

Yates, D., Seiber, J., Purkey, D., and Huber-Lee, A. (2005). "WEAP21—A demand-, priority-, and preference driven water planning model, Part 1: Model characteristics." J. Water Int., 30(4), 487-500. 